

\section{External Actors and Democratization Process in Nigeria's fourth Republic: The Case of the United States of America}

Prof. Femi Omotoso

Department of Political Science Ekiti State University

Ekiti State, Nigeria.

femot79@yahoo.co.uk

Dr. Olayide Oladeji

Department of Political Science Ekiti State University

Ekiti State, Nigeria.

yide.oladeji@gmail.com

Goke Kuti

Doctoral Candidate

Department of Political Science Ekiti State University

Ekiti State, Nigeria. gokekuti@yahoo.com 


\begin{abstract}
This paper examines the role of external actors in the democratization process in Nigeria's Fourth Republic with a focus on the United States of America. Democracy promotion abroad is a relatively recent phenomenon in international relations. It became a focus of study and/or foreign policy consideration in international relations after the end of the Cold War, which made the US a unipolar global power. Thus, democracy promotion abroad since this time became a major element in the US foreign policy. This coincided with the demand for democratic change in Nigeria, which got to a head with the annulment of the June 12, 1999 presidential election by the military government of General Babangida. Thus, the motivation for this paper is the desire to understand the role of external actors, especially the US, in the democratization process in Nigeria's Fourth Republic. This aspect of the Nigerian-US diplomatic relations, especially in the Fourth Republic, has largely been ignored in the literature. To fill this identified gap in the literature, this paper seeks an answer to the question: can external governments and international institutions promote democratization or regime change in other countries? Specifically, this paper seeks to understand how and why the US has influenced the democratization process in Nigeria since 1999. The paper utilizes the historical method and relies on secondary data gathered from a variety of sources, especially official policy documents, text books, journal articles, unpublished theses, and the internet.
\end{abstract}

Keywords: Democratization, External Actors, Foreign Policy, Fourth Republic, Nigeria, United States. 


\section{Introduction}

The past three decades or so have witnessed a burgeoning literature on the role of external actors/factors in democratization (Pridham, 1991; Whitehead, 1991; Ottaway, 1997; Burnell and Calvert, 2005; Magen, 2009; McFaul and Youngs, 2009). Prior to the end of 'Cold War in the early 1990s, democratic building efforts and researches largely focused on domestic factors with little attention paid to external/international factors/actors. During this period, most International Relations' (IR) studies seldom discussed democratization, which was then considered an exclusive area for comparative politics ${ }^{1}$. Another reason for the lack of IR studies in democratization has to do with sovereignty. That is, the respect for the rights of individual states to run their internal affairs without undue interference from outside. Then, IR, as a field of study, was more concerned with how states and other powerful actors engage in diplomatic, economic and political relationships with less interest in domestic politics. Thus, not until the end of the Cold War, there were little international perspectives to democratization.

However, since the early 1990s, many democratization efforts have been externally influenced. The international dimension to democratization at the end of the Cold War was triggered by the studies on globalization, which resulted in the conceptualization of the international dimension to democratization in democratic diffusion and democratic promotion (Silander, 2017). Indeed, there was a consensus within the international community that issues of national sovereignty should not insulate a country's internal politics from outside observations, criticisms, or even intervention (Rakner, Menocal, and Fritz, 2007). During this period, democracy did not just emerge as a universal aspiration, but also international norms, indicating that it was legitimate to develop an interest in promoting and supporting democracy abroad (Bjørnlund, 2004; Burnell, 2000). Consequently, the post-Cold War world has witnessed concerted efforts by both international and local actors to push for

\footnotetext{
${ }^{1}$ This point, nevertheless, in 1978 Peter Gourevith published a seminal article in 1978, The Second Image Reversed: The International Sources of Domestic Politics, wherein he outlined a set of arguments for why and how to study the international causes of domestic outcomes. The study provides framework for several literatures that later emerge after the collapse of the Soviet Union and the spirited efforts by the West to transfer democracy abroad.
} 
democratic changes in many hitherto authoritarian military and/or one party centralized states in Latin America, Eastern Europe, Asia, and Africa. Much of the international efforts were (are) led by international organizations, especially the international financial, development and donor institutions/agencies, great power states like the United States (US), and supranational institutions like the European Union (EU).

Thus, at the twilight of the last century, there was a spread of new democracies in virtually all regions of the world - except the Middle East ${ }^{2}$ - replacing authoritarian/totalitarian states and military regimes. In fact, democracy promotion was then a significant part of development assistance. On the basis of this, "the 1990s witnessed a mushrooming of democracy assistance projects from bilateral governments and related efforts by non-governmental and multilateral organizations" (Rakner, Menocal, and Fritz, 2007: 1). By this time, democracy promotion and assistance has become internationalized. Indeed, the US, EU, individual European countries, and multinational institutions have engaged in a variety of democracy-promoting activities like advising political parties, training judges, providing aid to government agencies, strengthening civil society, engaging in civic education campaigns and helping to develop new constitutions and electoral laws (Rakner, Menocal, and Fritz, 2007).

However, while democracy promotion has become an integral part of IR, "the US is by far the single largest provider of democracy assistance internationally" (Finkel et al., 2006). In fact, for various ideological and pragmatic reasons, democracy promotion abroad, in the recent past, has become a primary component of the US foreign policy active pursuit (Patterson, 2012; Epstein, Serafino and Miko, 2007; Aka, 2002; Nyinguro, 1999; Muravchik, 1991). Thus, the motivation for this paper is the desire to understand the role of external actors, especially the US, in the democratization process in Nigeria's Fourth Republic. This aspect of the Nigerian-US relations, especially in the Fourth Republic, has largely been ignored in the literature.

\footnotetext{
${ }^{2}$ However, the Middle East witnessed, in the early 2010s, an unprecedented series of 'citizen action' or pro-democracy uprisings/revolutions in many Arab countries like Tunisia, Morocco, Egypt, Libya, Bahrain and Syria, which is code-named the Arab Spring. The Arab Spring brought unprecedented socio-political changes to these countries, while the situation in Syria has resulted in an ongoing 'civil war'.
} 
Indeed, most of the literature on Nigeria's relation with the US in Fourth republic have largely concentrated on four main issues of military and security sector reform assistance, global war on terror, trade and investment, and debt relief and financial assistance (Alao, 2011).

Thus, to fill this identified gap in the literature on Nigeria-US relations, this paper seeks an answer to the question: can external governments and international institutions promote democratization or regime change in other countries? Specifically, this paper seeks to understand how and why the US has been influencing democratization process in Nigeria since 1999. The paper uses the historical method and relies on secondary data gathered from a variety of sources, especially official policy documents, text books, journal articles, unpublished theses, and the internet to provide answer to the why and how the US has been involved with democratization in Nigeria's Fourth Republic.

\section{External Actors and Democratization: A Review of the Literature}

As argued supra, there has been a burgeoning body of literature on the role of external actors in democratization since the end of the Cold War. Much of the literature on the role of external actors in democratization have largely been influenced by the need to provide answers to these questions: what is the motivation for a state to intervene in the democratization of another? To what extent can an external actor influence or impose democratization/regime change in/on another country? What is the relationship between national interest and promotion of democracy in the foreign policy of the intervening country? How do external actors influence democratization in practice? However, before providing answers to these questions, it is pertinent to understand the concept of 'democratization'. In fact, whether or not it is possible for external actors to promote democratization in another country will depend on the understanding of what aspects of the democratization process are amenable to external influence.

In the main, if democracy is conceptually and theoretically, at times ideologically, contested and unsettled, then democratization "cannot be defined by some fixed and 
timeless objective criterion" (Whitehead, 2002: 26). Thus, the literature on democracy tends to view democratization as a complex, long-term, dynamic, and open-ended process, which usually begins with "a passage from an essentially authoritarian regime to a basically democratic one" (Ogot, 1995: 245) and progresses towards a more rule-based, more consensual and more participatory type of politics (Whitehead, 2002). For the purpose of this paper, democratization is taken as a process (something ongoing) - transitioning from dictatorial rule and struggling between democratic and authoritarian elements to achieve a more stable and longstanding open and competitive multiparty electoral system with a view to achieving a broad-based participatory governance and development. However, what is the extent to which external actors can influence this process? Can external actors impose democratization on another country? Or at what stage in the democratization process does the influence of external actors most pronounce and effective?

While, arguably, contemporary scholarship has gone beyond the description of external dimensions of democratization as the 'forgotten dimension' (Pridham, 1991: 18; Burnell \& Calvert, 2005), it is still, nonetheless, difficult for scholars to agree on how external actors influence democratization. For instance, while agreeing that external actors can, and, indeed, do influence democratic transitions, it is, however, argued that democracy cannot be imposed from outside and that it, instead, springs from conditions within a country (Nyinguro, 1999: 48). That is, whatever may be the intention of an external actor at instigating/promoting democracy in another country, its impact and influence "are largely conditional on opportunities presented by domestic developments" (Pridham, 1991: 5). In fact, Schmitter (1986: 5) asserts that "...transitions from authoritarian rule and immediate prospects for political democracy were largely to be explained in terms of national forces and calculations. External actors tended to play an indirect and usually marginal role...." Thus, arguing for empirical reality in democratization, Whitehead argues that:

...democratization was plausibly viewed as an uncertain undertaking, one that would have to be internally driven, one that was potentially counterhegemonic and therefore most likely to succeed when domestic strategic interactions favoured agreement, and when external 
destabilizing pressures could be minimized. The relevant unit of analysis was thus the individual state (or national political regime), and attention was focused on those states that possessed sufficient internal autonomy to screen out international intrusions (Whitehead, 2004: 135, cited in McFaul and Youngs, 2009: 13-14).

Similarly, from his study of the US policy on democratization in Latin America, Drake (1991: 3) concludes that "the US failed to instil democracy abroad because it was very difficult to impose that political system through external meddling. Instead, democracy normally needed to grow out of internal conditions." In the specific case of Africa, Marina Ottaway warns that no amount of 'engineering' from outside will bring democratic results in Africa's democratic transitions because conditions in most African countries are still largely inhibitive as far as democratization is concerned (Ottaway, 1997). Ottaway, therefore, concludes that "democratization is, first and foremost, a domestic battle to which outsiders can only make a minimum contribution" (Ottaway, 1997: 15). Indeed, Abraham Lowenthal vividly captures the limitations of external actors in democratization when he argues that:

Democracy is not an export commodity; it cannot simply be shipped from one setting to another. By its very nature, democracy must be achieved by each nation, largely on its own. It is an internal process, rooted in a country's history, institutions, and values; in the balance of its social and economic forces; and in the courage, commitment, and skill of its political leaders and of plain citizens (Lowenthal, 1991: 402).

However, events since the aftermath of the Cold War and the September $11^{\text {th }}$ attacks on the US have radically transformed the study of democratization and the role of external actors in it (Carothers, 1994; Nyinguro, 1999; Megan, 2009; Megan \& McFaul, 2007; Whitehead, 2004). Indeed, these events have helped produce "an explosion of international political and economic incentives for states to qualify as democracies" (Whitehead, 2004: 136). These incentives are increasingly being institutionalized in the practices of international organizations (Magen, 2007), and codified in international law (Fox \& Roth, 2000). Thus, the international norms of non-intervention in internal affairs have eroded (Megan \& McFaul, 2007), international elections monitoring has become ubiquitous (Santa-Cruz, 2005), and 
more international actors - states, regional and global institutions, Non-governmental Organizations (NGOs) and activist networks - now employ more resources for democracy promotion and deploy more intrusive instruments of socialization and conditionality than ever before (Magen, 2009).

But, what is the extent to which external actors can influence democratization abroad? To answer this question, scholars have distinguished between 'political liberalization' and 'democratization', "with the former seeing as the opening up of the political system by removing barriers to democracy, while the latter refers to the whole process of the consolidation of democratic institutions and values and the evolution of a pattern of behaviour conducive to democratic ideals" (Nyinguro, 1999: 50). But, it must be pointed out that there is no watertight distinction between the two stages as elements of either may be present in the other process at the same time. In fact, and as argued earlier in this paper, democratization itself is a process, which involves continuous evolution and strengthening of its democratic ideals. However, scholars tend to agree that external influence on democratization is most noticeable and effective at the political liberalization stage of the democratization evolution. As Thomas Carothers remarks, when great powers like the US claim to promote democracy abroad, they only help to "initiate processes of democratization: the endpoint of a consolidated democracy is usually far from view in efforts to promote democracy" (Carothers, 1994: 51).

But Carothers' assertion may not be absolutely true or correct. Indeed, Whitehead contends that external actors can influence democratization in three significant ways:

pressure on undemocratic governments to democratize themselves; support for fledgling democracies that are attempting to consolidate; and the maintenance of a firm stand against anti-democratic forces that threaten or overthrow established democracies (Whitehead, 1991: 44).

Thus, it is based on Whitehead's assertion that this paper seeks to examine the role of the US in democratization in Nigeria's Fourth Republic starting from the pre-transition pressure on the Abacha's military junta, the support for the transition to 
democracy under General Absalami Abubakar, the stance against the third term agenda of President Olusegun Obasanjo, the pressure on President Goodluck Jonathan to peacefully hand over power to Muhammadu Buhari, and the current opposition to the anti-democratic posture of the Buhari administration. But beyond this, the study is interested in x-raying the underbelly interests of the US in pushing for democratization in Nigeria. That is, the study wants to see the connection between the US national interests and the promotion of democratization in Nigeria.

\section{Democracy Promotion as Foreign Policy: The US Case}

Starting from 1898 when President McKinley waged a war against Spain to 'restore respect of human rights' when the latter unlawfully possessed the Western Hemisphere, the US's foreign policy has consistently favoured political intervention in other countries for the sake of democracy promotion (Patterson, 2012; Nyinguro, 1999). An enduring aspect of the US foreign policy, apart from peace, prosperity and stability, has been the penchant for the 'spread of democracy' worldwide (Kegley \& Witkoff, 1996: 31). In fact, two American Presidents - Woodrow Wilson and Franklin Roosevelt - justified the US involvement in the First and Second World Wars as the necessary intervention for democracy (Nyinguro, 1999; Patterson, 2012). Thus, Fabio Fiallo argues that:

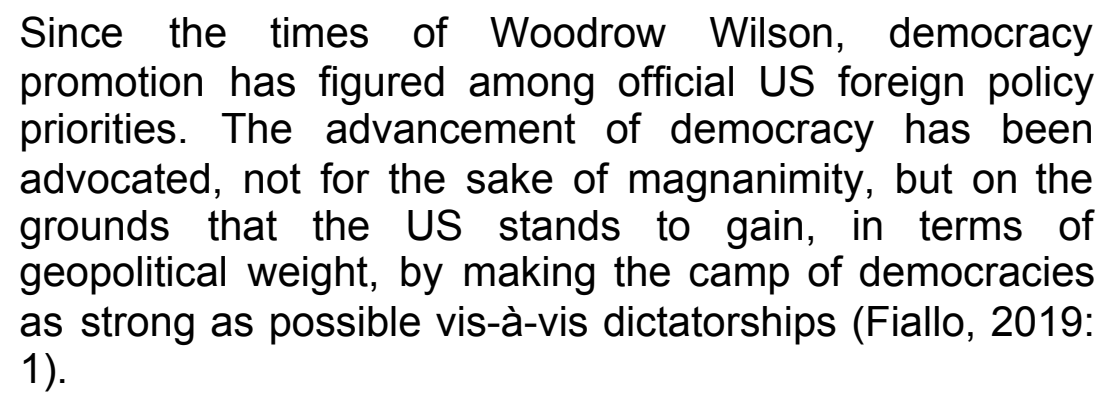

However, in the aftermath of the September $11^{\text {th }}$ attacks on the US and more broadly with the George W. Bush administration, the US has viewed democracy promotion as a foreign policy instrument for promoting peace and combating terrorism (Epstein, Serafino \& Miko, 2007). Specifically, during his second term inauguration address, Bush identified democracy promotion as a central focus of the American foreign policy on the 'war on terrorism' and national security. He stated that: 
....it is the urgent requirement of our nation's security.... So it is the policy of the United States to seek and support the growth of democratic movements and institutions in every nation and culture, with the ultimate goal of ending tyranny in our world (Bush, 2005 cited in Epstein, Serafino \& Miko, 2007: 1-2).

In fact, the Bush administration's approach to democracy promotion abroad evolved into what was then known as the Freedom Agenda (Patterson, 2012). The Freedom Agenda was not just a tertiary policy priority, nor was it rhetoric without action but it was an integral part of the US foreign policy under Bush, which was repeatedly called one of America's 'vital interests' (Patterson, 2012: 29). As part of his administration's democracy promotion worldwide, Bush initiated democracy awards such as the Human Rights Defenders Fund as well as engaged in multilateral democracy promotion by proposing and launching the United Nations (UN) Democracy Fund, the Roundtable on Democracy at the UN General Assembly, the G-8's Partnership for Progress, and a Common Future for countries in the 'Broader Middle East and North Africa' (BMENA) (Patterson, 2012: 29). However, the Bush's administration democracy promotion suffered a serious backlash, especially by associating it with the war and regime change in Iraq. Bush was equally criticised of double standards for casting the war on terrorism as a global 'freedom agenda' and yet tolerating and cultivating close ties with autocratic regimes helpful to his counterterrorism ${ }^{3}$. It is argued that his administration badly damaged America's standing as a global symbol of democracy (Carothers, 2009).

Thus, President Obama, on assumption of office, tried to avoid the pitfalls of the Bush administration. Though the Obama administration did not make democracy promotion the main element of its foreign policy orientation, it, nevertheless, did

\footnotetext{
${ }^{3}$ However, the ambivalence between democracy promotion and the US interest did not start with the Bush administration as this has been recurrently part of the US foreign policy. In fact, the US has sometimes been forced to intervene on behalf of clearly undemocratic forces in certain countries where the incumbent regimes which may be democratic are perceived to be hostile to American security and business interests (Nyinguro, 1999: 55). For example, the Jimmy Carter administration supported Cold War allies most notably the Shah of Iran and oil-rich Saudi Arabia (still a strategic American partner till date) despite their lack of democratic credentials (Patterson, 2012). Similar argument can be advance for the US intervention in Libya to ousted Gadhafi and its support for the rebels in Syria trying to topple the government of Bashar Al'Ashad. For a detailed analysis on democratic ambivalence in the US foreign policy see Lloyd Ambosius (2002), Wilsonianism: Woodrow Wilson and His Legacy in American Foreign Relations, New York: Palgrave.
} 
emphasise and articulate a vision for the US support for 'sustainable democracy'. While Obama maintained that 'no system of government can or should be imposed on one nation by another' (Obama, 2009 cited in Joseph, 2012.), his administration ended up maintaining many of the democracy-supporting policies of the Bush era (Patterson, 2012). For instance, on his tour of Africa in 2009, President Obama, while talking on his administration's readiness to challenge leaders whose actions threaten the credibility of democratic process, declared that:

Our message to those who would derail the democratic process is clear and unequivocal: The United States will not stand idly by when actors threaten legitimately elected governments or manipulate the fairness and integrity of democratic process (Obama, 2009 cited in Joseph, 2012: $1)$.

In fact, the Obama administration designed a specific policy for democracy development in Africa contained in "The Strategy" (Joseph, 2012). Despite the many undemocratic characteristics and/or posture of President Donald Trump, he has, so far, maintained the same democratic foreign policy similar to that of the Bush and Obama administrations (Fiallo, 2019). For example, in his address to the UN General Assembly in 2018, Trump stated that "the United States will not tell you how to live, or work or worship. We ask only that you honour our sovereignty in return" (Trump, 2018, cited in Fiallo, 2019). While many have criticised Trump for this statement, labelling it undemocratic and uncharacteristic of an American President, Fiallo (2019) argues that there has not been much difference in Trump's disposition to democracy promotion abroad as that of his predecessors. The only difference may be in approach and style. In fact, there has been bipartisan bias in favour of democracy promotion abroad between the Republican and Democrat Presidents and politicians in the US over the post-Cold War era (Epstein, Serafino \& Miko, 2007; Muravchik, 1991; Nyinguro, 1999).

In the specific case of Africa nay Nigeria, the US's contribution to democracy promotion is mixed. According to Diamond (1995: 252), "the US policies toward Africa have, since 1990, been increasingly driven by a concern for democracy, accountability, and human rights." The main body through which the US promotes 
democracy in Africa nay Nigeria is the US Agency for International Development (USAID). The USAID democracy promotion efforts are carried out through the Development Assistance programme known as Democracy and Governance (D\&G). D\&G mainly aims at promoting democracy by "strengthening the rule of law and respect for human rights, promoting genuine and competitive elections and political processes, encouraging increased development of a politically active civil society, and promoting more transparent and accountable governance" (Copson, 2007: 80). Also, the US government provides funds for the National Endowment for Democracy (NED) to lead democracy promotion abroad. NED was founded under the Reagan administration as a private and non-profit organization even though nearly all its funds are provided by the US government (Copson, 2007). The NED's stated objective is 'to strengthen democratic institutions around the world through nongovernmental efforts' (https://www.ned.org/about/).

However, the democratic efforts of USAID and NED in Africa are funded at modest levels and are mostly channelled to countries that are of most interest to the US government. Indeed, and as Copson remarked:

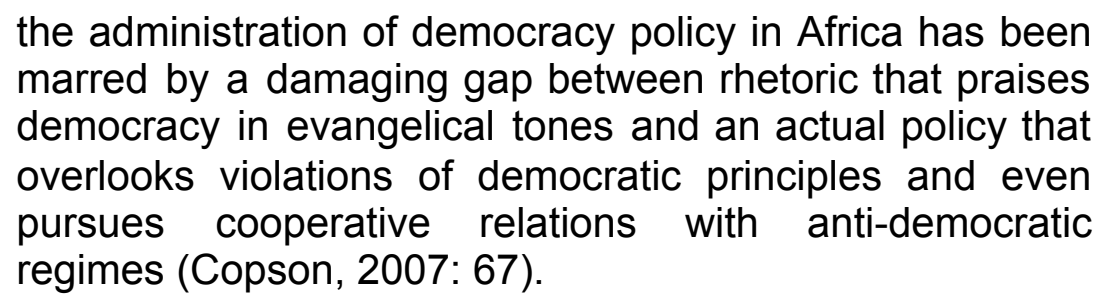

As we will show later, the US often places its energy and security interests in Africa, especially in Nigeria, beyond democracy promotion. Thus, the study aims at providing a balance sheet account of the US involvement in democracy promotion in Nigeria vis-à-vis the protection of its national interests in oil supplies and the security challenges posed to this in the Niger Delta region of Nigeria. However, before this is done, it is necessary to provide a background information on Nigeria's Fourth Republic.

\section{The Evolution of the Fourth Republic: The Internal-External Motivations}


Nigeria is a post-independence state with a very tortuous political history. The country gained its political independence from Britain on October 1, 1960. At independence, Nigeria had three regions effectively under the control of its three major ethnic groups ${ }^{4}$. Furthermore, Nigeria is a multinational federation with "over 374 ethnic groups ${ }^{5}$, over 400 distinct languages (as against dialects), at least three groups of belief-systems (Christians, Muslims, adherents of African Traditional Religions) as well as a large variety of customs..." (Tamuno, 1998: 22). Weaving these ethno-linguistic and religious groups together in an integral and coherent whole has been a major problem in Nigeria since independence (Oladeji, 2005: 6).

Regrettably, the inability of the Nigerian state to manage its plurality coupled with the issues of corruption and inability of the political class to successfully manage the pre and post-1964 election crisis resulted in the collapse of the First Republic and eventually plunged the country into three years of civil war between 1967 and 1970 . Since the events of this period, power has oscillated between democratically elected politicians and military rulers until May 1999 when power was eventually handed over to democratically elected politicians ${ }^{6}$. However, the period 1990 to 1999 was unprecedented in the political history of Nigeria.

On June 12, 1993, Nigeria conducted a presidential election that was adjudged the most credible in the history of the country. But, the election was annulled by the government of General Babangida based on flimsy excuses. The annulment drew both internal and external condemnations and would eventually propelled the democratic agitations that culminated into the transition programme of General Abdusalami administration between 1998 and 1999 after the death of General Abacha. Indeed, the annulment precipitated unprecedented political protests across

\footnotetext{
${ }^{4}$ The Hausa/Fulani in the North, the Igbo in the East, and the Yoruba in the West.

${ }^{5}$ There has not been an agreement among scholars and even policy makers on the number of ethnic groups in Nigeria. Afigbo (1986) put it at 250 ethnic groups, while Otite (1990) put it at 374.

${ }^{6}$ The military government of Obasanjo handed over power to elected civilians in 1979 on October 1, 1979 after an elaborate constitutional and transition to democracy process in what is now known as Second Republic. But, the republic only lasted for a period of 4 years before the military struck again on December 1, 1983. The Babangida administration's transition to democracy that would have ushered in the Third Republic ended up being 'a transition without end' as he hurriedly handed over to an interim government on August 27 1993, while the Third Republic became a stillborn. General Abacha who seized power from the interim government would embark on another transition that would allow him transmute as civilian president. His sudden death in June 1998 eventually paved the way for transition to democracy in the Fourth Republic in 1999.
} 
the country by many pro-democracy organizations and labour unions to demand for the announcement of the June 12 presidential election results. Furthermore, the political class together with civil society groups as well as the mass media extensively and effectively employed anti military publications and reportage to expose the evil of the military regimes in order to mobilize the mass of the people against military rule (Esebonu, 2012: 183). This resulted in arbitrary arrest and detention of politicians and pro-democracy activists, closure and seizure of media houses and publications. In fact, some activists exiled themselves from the country in order to escape military brutality including state sponsored political assassinations. Thus, episodes of mass protest and industrial action across the country by various civil society groups, labour unions, and pro-democracy organizations as well as Abacha's death necessitated transition to democracy of General Abdulsalam.

On the other hand, the international dimension to the transition to the Fourth Republic could be explained from different standpoints. First and foremost, the pro-democracy agitations within the country could be said to have been affected by what Samuel Huntington refers to as the "snowballing effects" (Huntington, 1993). This means that democratization is contagious. Thus, the wave of democratization ravaging the world starting with the collapse of the Soviet Union and the 'triumph of democracy' spurred Nigerians into demanding transition to democracy. For example, as the chairman of conference of the African Leadership Forum in April 1990, a former Nigerian Military Head of State ${ }^{7}$, General Olusegun Obasanjo, remarked that:

The changes taking place in Eastern Europe have far-reaching political implications for the Third World in general and for Africa in particular. The winds that swept away dictatorships and autocratic one-party systems and State structures, inefficient economic systems and unresponsive social institutions in Eastern Europe, and fuelled a democratic rejuvenation and the observance of human rights, are not unfamiliar to Africa. The winds of change in Eastern Europe are providing considerable opportunities for the African people and oppressed peoples the world over to intensify their just struggle for

\footnotetext{
${ }^{7}$ Obasanjo would later become the first beneficiary of the transition to democracy that started in Nigeria in the early 1990s when he was elected and inaugurated as Nigeria's civilian president in May 1999.
} 
democracy (Obasanjo, 1990 cited in National Research Council, 1992: 1).

That is, the globalization of ideas and the myriad of changes taking place in the world emboldened African nay Nigerian individuals to speak up and demand for change. In what was then referred to as the 'second wave of liberation in Africa', demands for transition from authoritarianism to more democratic forms of governance were widespread in the continent.

Apart from the snowballing effects and as argued before in this paper, democracy promotion in the post-Cold War era constituted a formidable part of development aid assistance (Jega, 2007; Brown, 2005). For instance, USAID in Africa intensified its efforts to press for and support transitions from authoritarian rule to democracy and from state-administered to market-driven economies. In fact, the new insistence by external aid donors and creditors on good governance provided a window of opportunity for African democrats to push for democracy, transparency, and accountability in their countries (National Research Council, 1992: 3). In the specific case of Nigeria and when the June 12, 1993 election was annulled, the US government suspended non-humanitarian assistance to Nigeria, reduced the level of military personnel exchange between the two countries, reviewed all new application for exports of defence articles and services to Nigeria, imposed restrictions on the issuance of American diplomatic visas to Nigerian officials, and advised prospective American visitors to avoid Nigeria (Dickson, 2013: 201). In short, the impact of internal events within Nigeria coupled with external pressures, had direct and indirect effects on the transition programmes that led to Nigeria's Fourth Republic.

\section{The US and Democratization Process in Nigeria's Fourth Republic}

This section of the paper seeks to answer the question: how and why has the US been involved in democratization in Nigeria's Fourth Republic? Thus, the section historicises the role of the US in Nigeria's democratization, especially starting with the transition programme under General Abdulsalam Abubarka, which eventually metamorphosed into what is now called the Fourth Republic in Nigeria. As noted above, the sudden death of General Abacha, which stopped his self-succession 
ambition to transmute into a democratic leader, paved the way for the emergence of a new democratic transition under the administration of Abdulsalam. Indeed, given the tensed political atmosphere within and without Nigeria then, the new government of Abdulsalam had little or no choice than to terminate the 'flawed Abacha transition' and to commence a fresh transition programme of his own. One fact that cannot be downplay was the pressure mounted on the Abdulsam administration by external actors, especially the US, to ensure a regime change without wasting time. For example, after the initial gaffe of President Bill Clinton on the Abacha transition ${ }^{8}$, the US State Department in April 1998 declared that "the current transition process appears to be gravely flawed and failing. We do not see how the process, as it is now unfolding, will lead to a democratic government (Constitutional Rights Project, 1998: 8 quoted in LeVan, 2019: 39). Indeed, after the death of Abacha, the then State Department spokesman, James Rubin, stated that Abubakar had:

a historic opportunity to open the political process and institute a swift and credible transition to civilian democratic rule.... Washington would accept only a transition that include three things: first, freeing political prisoners; second, ensuring respect for the basic freedoms of speech, press, and assembly; and third, returning the Nigerian army to its rightful position as a professional armed force committed to defending the constitution and civilian rule (Rubin, 1998 cited in Dagne, 2005: 12).

Also, President Clinton impressed it on Abdulsalam that the United States' desire for improved bilateral relations in the context of Nigeria taking swift and significant steps toward a successful transition to a democratically-elected government (Dagne, 2005: 12). Thus, given the mounting pressure from within and without Nigeria, Abubakar, in an address to the nation entitled 'The Way Forward', declared the cancellation of the flawed Abacha transition programme, which he said was necessary to ensure a true and lasting democracy in Nigeria (LeVan, 2019). He equally promised to release all

\footnotetext{
${ }^{8}$ Bill Clinton, during a visit to South Africa in March 1998, referring to Abacha's attempt to transmute to civilian president, stated that "if he stands for election, we hope he will stand as a civilian. There are many military leaders who have taken over chaotic situations in African countries, but have moved toward democracy. And that can happen in Nigeria; that is, purely and simply, what we want to happen" (Clinton, 1998 quoted in LeVan, 2019: 39). Clinton was widely criticised by pro-democracy activists in Nigeria and outside the country for this statement.
} 
political prisoners and withdraw pending political charges. With this same token, he dissolved all the political parties, stating that every Nigerian citizen has equal opportunity to form or join any political party in line with guidelines to be determined by a new electoral commission. He stated also that elections would be held in the first three months of 1999 and the power would be handed over to a civilian President on May 29, 1999. Indeed, it was reported that Abubakar's address was intended to "convince the United States and other Western governments that a page has been turned in Africa's most populous nation...." (Cohen, 1998: 1).

Abubakar kept his promise, as elections were held as scheduled and by May 29, 1999, he handed over power to Chief Olusegun Obasanjo of the People's Democratic Party (PDP), who won the presidential election. Apart from mounting pressure for the transition, the US government, through some NGOs, closely monitored the whole process, especially the elections ${ }^{9}$. For instance, the report on the electoral process by the Washington-based National Democratic Institute, while praising Abubakar for his role, condemned his overbearing influence. The report noted that "from the onset, a compressed timetable and top-down structure controlled by the very military officials it intended to replace affected the process" (Carter Centre and National Democratic Institute for International Affairs, 1999: 32). In fact, in a letter to INEC Chairman signed by President Jimmy Carter on behalf of The Carter Centre, he complained that:

... a wide disparity between the number of voters observed at the polling stations and the final results that have been reported from several states. Regrettably, therefore, it is not possible for us to make an accurate judgment about the outcome of the presidential election (Carter Centre and National Democratic Institute for International Affairs, 1999: 12).

However, despite the noticeable flaws in the electoral process and the elections, Abubakar was celebrated both by internal and external pro-democracy actors for

\footnotetext{
${ }^{9}$ The Carter Centre and the National Democratic Institute for International Affairs led by a former American President, Jimmy Carter, were involved at all stages of the transition working closely with the Transition Monitoring Group (TMG). For full details on the Carter Centre and NDI's involvement in the transition, see Carter Centre and NDI (1999), Observing the 1998-1999 Nigeria Elections: Final Report.
} 
peacefully transiting power to civilian elites as promised. Has the US been involved in democratization in Nigeria beyond the 'political liberation' stage? Or, how has the US been engaging in the democratic process beyond the 1998-1999 transition stage? As argued before in this paper, international actors' involvement in democratization abroad is usually more noticeable at the transition stage. But, this does not mean, as Whitehead (1991) argued, that international actors do not influence democracy abroad beyond the transition period. In the specific case of the US and democratization in the Fourth Republic, the US has been a major international actor in Nigeria's democratization since 1999 when it returned to democracy.

As noted before, the US democracy promotion abroad is usually channelled through its international organizations like USAID, NED, NDI, etc. Indeed, the USAID's democratic support in Nigeria has been through the Consortium for Electoral and Political Processes (CEPPS), which consists of three United States NGOs: NDI, NED, IRI (the International Republican Institute), and IFES (the International Federation for Electoral System). For instance, the NDI, in 1999, initiated a four-year legislative training support programme in Nigeria amounting to a total sum of USD 4.54 million. The training involved budget analysis, rules and procedure, the role of committees, legislative drafting, constituency relations, civil society engagement, and the development of the legislative ICT centre $^{10}$ (Adetula, Kew \& Kwaja, 2010: 4). Furthermore, IFES technical assistance and the electoral support to INEC worth USD 4.3 million as at December 2003 (Adetula, Kew \& Kwaja, 2010). Between 2007 and 2009, USAID estimatedly spent USD 49.79 million for various forms of democratic assistance in Nigeria (Sule, Wurobokki \& Sambo, 2018: 83). In 2018, USAID and the Department for International Development (DFID) amended a Memorandum of Understanding (MOU) to extend their joint funding arrangements to support Nigeria's electoral process through 2020. The amended MOU would take the joint funding support for free, fair, transparent, and peaceful Nigerian elections to USD 60 million over six years (USAID, 2020).

\footnotetext{
${ }^{10}$ Similarly, in 1999, a four-year state legislative strengthening programme of USD 4.2 million was provided by the Mississippi Consortium for International Development (MCID) for states assemblies in Adamawa, Benue, Edo, Enugu, Katsina, Lagos, Niger, and Rivers through USAID (Oyinlola \& Griffi, 2003).
} 
Similarly, since 1999, NED has been promoting democracy in Nigeria through funding activities to provide access to justice for pre-trial detainees, increase women's participation in the political process, defend journalists who report on corruption, empower youth for effective democratic participation, foster civil-military dialogue, etc. (NED, 2018). Apart from the obvious involvement of the US in Nigeria's democratization, it has equally been involved through what Copson (2007) referred to as 'quiet diplomacy', which is usually through its officials outside public channels. For instance, in 2005, the US, through its Director of National Intelligence, warned against constitution amendment in Nigeria to pave way for President Olusegun Obasanjo to contest for a third term in office (Copson, 2007: 83). In fact, some praised the US 'quiet diplomacy outside public channels in making Obasanjo succumb to the anti-third term agenda within Nigeria (Lyman, 2007). The US, however, issued an official message through its embassy in Abuja after Obasanjo agreed to drop the third term agenda (This Day, 31 May 2006).

Furthermore, to support Nigeria's fledgling democracy and maintain a firm stand against anti-democratic forces in Nigeria, the US has been particularly critical of flawed elections in the country, especially in 2007, 2015 and 2019. The 2007 elections in Nigeria were marred by various forms of irregularities. What discouraged Nigerian and international observers, especially the US, was the brazenness with which rigging, intimidation, ballot stuffing, and outright fraud took place during the election. Thus, it is argued that "Nigeria went from being a paragon of the democratization process to being an uncertain political entity" (Lyman, 2007). The US was also very critical of the preparation for the 2015 elections, especially when voting was postponed for six weeks by the government of President Goodluck Jonathan because of the security situation in the North eastern part of Nigeria. Reacting to the excuse for the postponement provided by Prof. Atahiru Jega, the then INEC Chairman, the US Secretary of State, John Kerry, said:

Political interference with the Independent National Electoral Commission is unacceptable, and it is critical that the government not use security concerns as a pretext for impeding the democratic process...The international community will be watching closely as the 
Nigerian government prepares for elections on the newly scheduled dates. The United States underscores the importance of ensuring that there are no further delays...As I reaffirmed when I visited Lagos last month, we support a free, transparent, and credible electoral process in Nigeria and renew our calls on all candidates, their supporters and Nigerian citizens to maintain calm and reject election-related violence (Kerry, 2015 quoted in Larryfatty Blog, February 9, 2015).

In fact, Jonathan said he lost his re-election in 2015 to the unnecessary meddling in Nigerian politics by some international actors, especially the United States ${ }^{11}$, the United Kingdom and France ${ }^{12}$ (Saharareporters, April 26, 2017). The All Progressives Congress (APC) complained about the same thing about President Donal Trump in the run up to the 2019 general elections in Nigeria, especially when the main opposition's, PDP, candidate, Alhaji Atiku Abubakar, was granted visa and eventually allowed into the United States despite a corruption case against him in the US for his role in the Halliburton gate. The criticism of meddling in Nigerian internal politics and, at times, over reliance on some external actors' involvement by local politicians to win elections, lend credence to what Caryn Peiffer and Pierre Engelbert refers to as 'extraversion in African politics' (quoted in Joseph, 2012). Extraversion as a concept refers to susceptibility of African countries, especially governments, to external influence (Joseph, 2012). Thus, both initial transitions and subsequent democratic consolidation reflect the differing degrees of regime extraversion in Nigeria.

But, why is the United States interested in Nigeria's democratization? Is the involvement of the US in the interest of Nigeria or for the advancement of its national interests? According to Fasakin (2015: 306), "the Nigerian state and its democratization process have been of interest to the international community not for causal reasons". Indeed, and as argued by Slaughter (2000), most foreign political actions are not usually based on goodwill but are often rooted in prudence and practicability. While democracy promotion, as argued earlier in this paper, may be a

\footnotetext{
${ }^{11}$ For a detailed analysis on the role of the US, especially President Barack Obama, in the election and the eventual loss of Jonathan, see Olusegun Adeniyi (2017), Against the Run of Play: How an Incumbent President was Defeated in Nigeria, Kachifo Limited, Lagos.

${ }^{12}$ It is, however, interesting to note that the same international actors joined forces with some pro-democracy activists in Nigeria to ensure that Jonathan was install first as acting President and later as President when President Musa Yar'Adua eventually died in 2010.
} 
sufficient national interest in the US foreign policy, such idealistic abstraction is usually based on more concrete or material considerations (Aka, 2002). In fact, since every nation determines its policies in terms of its own national interests, the US foreign policy "encompasses both moral idealism and raw self-interests (Akande, 1999).

Thus, beyond democracy promotion in Nigeria, a primary United States' interest in Nigeria has usually been oil (Aka, 2002; Lauren, 2012; Fasakin, 2015; Lauren \& Tomas, 2019). Indeed, since 1974, Nigeria has been one of the largest exporters of crude oil to the US (Minter, 2000; Lauren, 2012). The low sulphur content in Nigerian crude and its proximity to the US relative to the Middle East countries particularly make Nigeria's oil attractive to the US interests (Lauren \& Tomas, 2019). In fact, the US imports over $40 \%$ of Nigeria's total crude oil exports make it Nigeria's largest trading partner (Ibid). Also, American companies - Shell, ExxonMobil, and Chevron have always been major players in Nigeria's oil industry.

Another major attraction for the US interests in Nigeria has been the strategic position of Nigeria in Africa as the most populous nation and the largest economy in the continent ${ }^{13}$. The population has large potential for manufactured goods, which make Nigeria a huge market for American goods. It is against this backdrop that scholars are of the view that the promotion of certain sacrosanct national interests guides foreign interference(s) in Nigeria's democracy (Fasakin, 2015). In fact, the presence of these international actors, especially the US, in the economic activities of Nigeria is not exclusive of their involvement in Nigeria's political happenings. The US interest is the maintenance of American cultural-historical linkages to Nigeria. Indeed, a great deal of Black-Americans trace their roots to Nigeria (Aka, 2002).

Furthermore, the promotion of democracy in Nigeria has ideological undertone. As argued before in this paper, there have been exponential efforts in international promotion of democracy with the collapse of the Soviet Union and the triumph of the US as the international unipolar power. Thus, its democratic promotion efforts in

\footnotetext{
${ }^{13}$ Nigeria used to be the second largest economy in Africa until February, 2020 when the South African economy entered recession for the second time in recent history.
} 
Nigeria could be explained as having a lot to do with having its democratic foothold in the most populous black nation and a sub-regional hegemonic power. For example, even when Nigeria was still under the military rule, especially under Babangida and Abacha, the US praised and supported Nigeria's democratic promotion efforts in Liberia and Sierra Leone. Under Abacha and as part of the Economic Community of West African States Monitoring Group (ECOMOG), Nigeria led a peacekeeping mission that helped to stabilize long-time US allies in the two countries. While the investment came at a very huge cost to Nigeria, it was, nevertheless, contributed to the US strategic goal of democracy promotion. Indeed, a former US Secretary of State, Madeleine Albright, stated that Nigeria is "...potentially a very valuable partner for us in promoting peace, democracy, and the rule of law throughout West Africa" (Albright, 1999). Thus, for the US, promoting and ensuring Nigeria remains a democratic state is part of its strategic interest of ensuring that democracy remains the 'only game in town' in Africa as well as to push for its twin sister, market economy, in the continent.

\section{Conclusion}

This paper examined the role of external actors in Nigeria's democratization process since 1999 with the main focus on the role of the US in the process. The paper argued that democratic promotion internationally was not so popular until the end of the Cold War in the early 1990s, which made the US a unipolar global power. Thus, democratic promotion abroad since this time became a major element in the US foreign policy. These events coincided with the demand for democratic change in Nigeria, which got to a head with the annulment of the June 12, 1999 presidential election by the military government of General Babangida. Despite the despotic tendencies of the Abacha regime, the yearning for a change did not wane in the country. Thus, with the death of Abacha, the US with other international allies as well as pro-democracy groups in Nigeria mounted pressure on General Abubakar to transit power to democratically elected officials. On May 29, 1999, Nigeria officially returned to the league of democratic nations. However, as argued in the paper, democratic building efforts may be difficult to impose from outside a state without a concomitant internal agitation by pro-democracy actors within the state. Lastly, the 
Journal of Science, Humanities and Arts

\section{paper argued that the democratic promotion activities of the US in Nigeria is more to achieve its other strategic interests not only in Nigeria but in Africa as a whole.}

\section{References}

Adeniyi, O. (2017). Against the Run of Play: How an Incumbent President was Defeated in Nigeria, Kachifo Limited, Lagos.

Adetula, V., Kew, D., \& Kwaja, C. (2010). Assessing Democracy Assistance: Nigeria. The United Nations Democracy Fund.

Aka, P. C. (2002). The 'Dividend of Democracy': Analyzing U.S. Support for Nigerian Democratization, Boston College Third World Law Journal, Vol. 22(2), pp. 225-280.

Akande, L. (1999). U.S. Keen on Nigeria's Reforms as Obasanjo Visits, Guardian Online, October 27.

Alao, A. (2011). Nigeria and the Global Powers: Continuity and Change in Policy and Perceptions. Occasional Paper No. 96. South African Institute of International Affairs.

Albright, M. K. (1999). On-the-Record Briefing on Secretary of State Trip to Africa, CTBT and Resources Washington, DC, October 25, 1999 As released by the Office of the Spokesman U.S. Department of State. https://1997-2001.state.gov/statements/1999/991025.html

Bjørnlund, E. C. (2004). Beyond Free and Fair: Monitoring Elections and Building Democracy. Baltimore, MD: Woodrow Wilson Center Press and the Johns Hopkins University Press.

Brown, S. (2005). Foreign Aid and Democracy Promotion: Lessons from Africa, The European Journal of Development Research, Vol. 17(2), pp. 179-198.

Burnell, P. (2001) Promoting Parties and Party Systems in New Democracies: Is There Anything the International Community Can Do? in K. Dowding et al. (eds), Challenges to Democracy. Basingstoke: Palgrave.

Burnell, P. and Calvert, P. (2005). Promoting Democracy Abroad, Democratization, 12/4: pp. 443-438.

Carothers, T. (1994). The Democracy Nostrum, World Policy Journal, XI (3).

Carothers, T. (2009). Democracy Promotion under Obama: Finding a way Forward, Policy Brief 77, Washington: Carnegie Endowment for International Peace.

Carter Centre and National Democratic Institute for International Affairs (1999). Observing the 1998-99 Nigeria Elections: Final Report, Special Report Series, Carter Centre and National Democratic Institute for International Affairs.

Cohen, R. (1998). New Nigeria Ruler Pledges Elections Early Next Year. The New York Times, July 21. https://www.nytimes.com/1998/07/21/world/new-nigeria-ruler-pledges-elections-early-next-year.html. Accessed on 17 February, 2020.

Copson, R. W. (2007). The United States in Africa: Bush Policy and Beyond, London: Zed Books.

Dagne, T. Nigeria in Political Transition, CRS Issue Brief for Congress, Congressional Research Service.

Diamond, L. (1995). Promoting Democracy in Africa: U.S. and International Policies in Transition, in John W. Harbeson \& Donald Rothchild (eds.), Africa in World Politics: Post-Cold War Challenges.

Dickson, M. E. (2013). An Assessment of the Diplomatic Relations between Nigeria and the United States of America in the Fourth Republic, African Journal of Social Sciences, Vol. 3(4), pp. 200-213.

Drake, P. (1991). From Good Men to Good Neighbors: 1912-1932, in Abraham F. Lowenthal (ed.), Exporting Democracy: The United States and Latin America, Baltimore: The Johns Hopkins University Press. 


\section{JOSHA}

Journal of Science, Humanities and Arts

Epstein, S. B., Serafino, N. M. and Miko, F. T. (2007). Democracy Promotion: Cornerstone of U.S. Foreign Policy? CRS Report for Congress, Congressional Research Service.

Esebonu, E.N. (2012). The Mass Media and the Struggle for Democracy in Africa: The Nigerian Perspective, Nordic Journal of African Studies, 21(4), 183-198.

Fasakin, A. (2015) State and Democratization in Nigeria, Democracy and Security, Vol. 11(3), pp. 298-317, DOI: 10.1080/17419166.2015.1068694.

Fiallo, F. R. (2019). In Democracy Promotion, Democrats do not Outperform Trump, International Policy Digest, August 21. https://intpolicydigest.org/2019/08/21/in-democracy-promotion-democrats-do-not-outperform-trump/. Accessed on February 5, 2020.

Finkel, S., Anibal, P. L., Mitchell, S. and Dinorah, A. (2006). Effects of US Foreign Assistance on Democracy Building: Results of a Cross-National Quantitative Study. Nashville, TN: Vanderbilt University.

Fox, G. and Roth, B. (eds.) (2000). Democratic Governance and International Law.

Gordon, D. F. (1997). On Promoting Democracy in Africa: The International Dimension, in Marina Ottaway (ed.), Democracy in Africa: The Hard Road Ahead, Boulder: Lynne Reinner.

Gourevitch, P. (1978). The Second Image Reversed: The International Sources of Domestic Politics, International Organization, Vol. 32(4), pp. 881-912.

Huntington, S. (1993). Democracy's Third wave, in Diamond, L. and Plattner, M.G (eds.), The Global Resurgence of Democracy, John Hopkins University Press, Baltimore and London.

Jega, A.M (2007). Democracy, Good Governance and Development in Nigeria: Critical Essays, Spectrum Books Limited Ibadan, Nigeria

Joseph, R. (2012). The American Presidency and Democracy Promotion in Africa, Brookings, August 23. https://www.brookings.edu/opinions/the-american-presidency-and-democracy-promotion-in-africa/\#page-content. Accessed on January 18, 2020.

Kegley, C. W. and Witkoff, E. R. (1996). American Foreign Policy: Pattern and Process (5th ed.), New York: St. Martin's Press.

Larryfatty Blog (2015). Jonathan Says Handover Date is Sacrosanct as US Decries Polls' Postponement, February 9. https://larryfatty08.wordpress.com/2015/02/09/jonathan-says-dandover-date-is-sacrosanct-as-us-decries-polls-postponement/. Accessed on 21 February, 2020.

Lauren, P. (2012), Nigeria: Current Issues and U.S. Policy, CRS Report for Congress, Congressional Research Service.

Lauren, P. and Tomas, F. H. (2019). Nigeria: Current Issues and U.S. Policy, CRS Report for Congress, Congressional Research Service.

LeVan, A. C. (2019). Contemporary Nigerian Politics: Competition in a Time of Transition and Terror, Cambridge: Cambridge University Press.

Lowenthal, A. F. (1991). The United States and Latin American Democracy: Learning from History, Abraham F. Lowenthal (ed.), Exporting Democracy: The United States and Latin America, Baltimore: The Johns Hopkins University Press.

Lyman, P. N. (2007). Democracy in Africa: Testimony, Council on Foreign Affairs, July 17. https://www.cfr.org/report/democracy-africa. Accessed on February 5, 2020.

Magen, A. (2007). Transformative Engagement Through Law: The Acquis Communautaire as an Instrument of EU External Influence, European Journal of Law Reform, Vol. 9(3), pp. 361-392.

Magen, A. (2009). Evaluating External Influence on Democratic Development: Transition, Center on Democracy, Development, and The Rule of Law Working Paper No. 111. Stanford: CDDRL 


\section{JOSHA}

Journal of Science, Humanities and Arts

Magen, A. and McFaul, M. (2007). Shared Ideal, Divergent Strategies? Explaining Similarities and Differences in EU and US Democracy Promotion, paper prepared for the American Political Science Association (APSA) 2007 Annual Meeting: Political Science and Beyond, Chicago, Illinois, August 30th - September 2nd, 2007.

McFaul, M. and Youngs, R. (2009). International Actors and Democratic Transitions: Ukraine 2004, Center on Democracy, Development, and The Rule of Law Working Paper No. 111. Stanford: CDDRL

Minter, W. (2000). America and Africa: Beyond the Double Standard, Current History.

Muravchik, J. (1991). Exporting Democracy: Fulfilling America's Destiny, Washington, D.C.: The AEI Press.

National Research Council (1992). Democratization in Africa: African Views, African Voices. Washington, DC: The National Academies Press. https://doi.org/10.17226/2041.

NED (2018). Nigeria 2018. https://www.ned.org/region/africa/nigeria-2018/. Accessed on February 5, 2020.

Nyinguro, P. (1999). United States Policy and the Transition to Democracy in

Kenya, 1990-1992. PhD Dissertation in Political science, University of South Carolina, Department of Government and International Studies Program in Political Science.

Ogot, B. A. (1995). Transition from Single-Party to Multi-Party Political System, in B.A. Ogot and W.R. Ochieng (eds.), Decolonization and Independence in Kenya, Athens: Ohio University Press.

Oladeji, I. O. (2005), Citizenship, Indigeneity and the quest for National Integration in Nigeria, Unpublished BSc Long Essay submitted to the Department of Political Science, University of Ado-Ekiti, Ado-Ekiti.

Ottaway, M. (1997). African Democratization and the Leninist Option, Journal of Modern African Studies, Vol. 35(1), pp. 1-15.

Oyinlola, Y. and Griffi, P. (2003). Evaluation of Support for Electoral Processes, Political Party development and Legislative Strengthening in Nigeria, USAID: Task Order \#1, Rapid Response; Contract \# AEP-1-00-00-00008-00. 2003. /.

Patterson, E. (2012). Obama and Sustainable Democracy Promotion. International Studies Perspectives, Vol. 13, pp. 26-42.

Pridham, G. (1991). International Influences and Democratic Transition: Problems of Theory and Practice in Linkage Politics, in Geoffrey Pridham (ed.), Encouraging Democracy: The International Context of Regime Transition in Southern Europe, New York: St. Martin's Press.

Rakner, L., Menocal, A. R. and Fritz, V. (2007). Democratization's Third Wave and the Challenges of Democratic Deepening: Assessing International Democracy Assistance and Lessons Learned, Research project (RP-05-GG) of the Advisory Board for Irish Aid, Overseas Development Institute

Santa-Cruz, A. (2005). Constitutional Structures, Sovereignty, and the Emergence of Norms: The Case of Election Monitoring, International Organization, Vol. 59, pp. 663-693.

Schmitter, P. (1986). An Introduction to Southern European Transitions, in Guillermo O'Donnell and Philippe Schmitter (eds.), Transitions from Authoritarian Rule: Southern Europe, Baltimore: Johns Hopkins University Press.

Silander, D. (2017). Building Democracy: National and International Factors, http://dx.doi.org/10.5772/intech open.71984. Accessed on January 25, 2020.

Slaughter, A. M. (2000). The Real New World Order, in O'Meara, P., Mehinger, H. D. and Krain, M. (eds.), Globalization and the Challenges of a New Century: A Reader, Indiana University Press.

Steven, F., Anibal, P.L., Mitchell, S. and Dinorah, A. (2006). Effects of US Foreign Assistance on Democracy Building: Results of a Cross-National Quantitative Study. Nashville, TN: Vanderbildt University.

Sule, B., Wurobokki, H. S. and Sambo, U. (2018). International Donor Agencies and Electoral Support in Nigeria's Fourth Republic (1999-2015): The Missing Link, International Journal of Social Science Research, Vol. 6(1), pp. 2327-5510.

Tamuno, T.N. (1998). Nigerian Federalism in Historical Perspective, in 'Kunle Amuwo et al (eds.), Federalism and Political Restructuring in Nigeria, Ibadan: Spectrum Books. 
Journal of Science, Humanities and Arts

November 2020

This Day (2006). Nigeria: Death of $3^{\text {rd }}$ Term, Victory for Democracy - US. 31 May.

USAID (2018). U.S. and U.K. Agree Continue Joint Funding of Elections Support, USAID, July 2.https://www.usaid.gov/nigeria/press-releases/july-2-2018-us-and-uk-agree-continue-joint-funding-elections-support. Accessed on February 5, 2020.

Whitehead, L. (1991). International Aspects of Democratization, in Guillermo O'Donnell, Phillipe C. Schmitter and Laurence Whitehead (eds.), Transitions from Authoritarian Rule: Prospects for Democracy, Baltimore: The Johns Hopkins University Press.

Whitehead, L. (2002). Democratization: Theory and Experience, Oxford: Oxford University Press. 
Journal of Science, Humanities and Arts

\section{Author's:}

\section{Dr. Olayide Oladeji (Corresponding Author)}

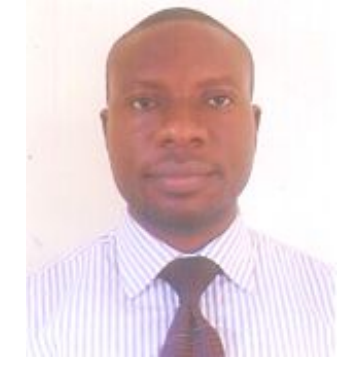

\section{Prof. Femi Omotoso}

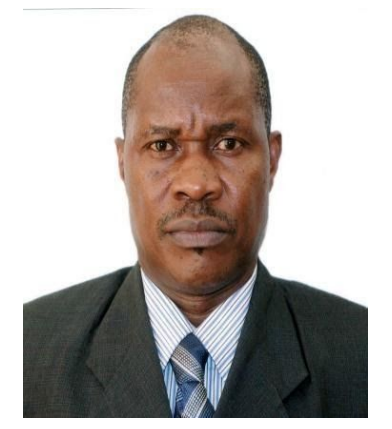

\section{Goke Kuti}

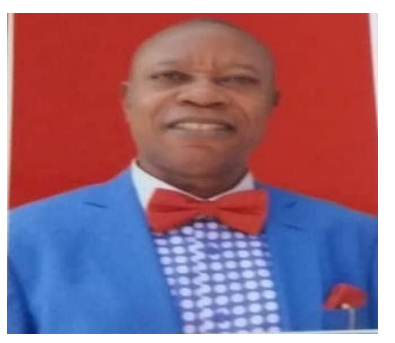

Goke Kuti is currently a PhD candidate in the Department of Political Science, Ekiti State University. His Doctoral research focuses on the Nigeria's external relations with the

superpowers, especially the United States and China, since her returned to a democratic order in 1999. Kuti has deep research interest in international affairs, especially as it affects Africa. He combines his academic pursuit with pastoral work at the Redeem Christian Church of God (RCCG) as the current Regional Head of RCCG Region 25, Ekiti State. 